\title{
Impact of Workers' Remittances on Household Welfare in District Jhang (A Case Study of Tehsil 18 Hazari)
}

\author{
Khawar Abbas ${ }^{1, *}$, Hazur Muhammad Sabir ${ }^{1}$, Anam Shehzadi ${ }^{1}$, Qamar Abbas ${ }^{2}$ \\ ${ }^{1}$ Department of Economics, G.C University, Faisalabad, Pakistan \\ ${ }^{2}$ Student of (BS) Economics, G.C University, Faisalabad, Pakistan \\ *Corresponding author: Khawar.economist@hotmail.com
}

Received February 26, 2014; Revised March 11, 2014; Accepted April 07, 2014

\begin{abstract}
The inflow of foreign remittances is continuously increased in Pakistan and it has been estimated that about 13186.58 \$ million received in the last fiscal year [23]. The main purpose of this study was to check the impact of remittances on household welfare as well as poverty of the household in Tehsil 18 Hazari, District jhang, Punjab, Pakistan. Household expenditures were used as a proxy variable to measure the welfare of household. Primary data were collected from the 9 union councils of Tehsil 18 Hazari. The size of sample was around 280, out of which 140 migrated households while 140 were non migrated. The results derived by application of OLS and logit model, revealed that education of household head, total number of animals, monthly income and foreign remittances were beneficial for improving the welfare of household while size of the house, marital status and dependency ratio negatively affected household welfare.
\end{abstract}

Keywords: workers' remittances, household welfare, poverty of the household

Cite This Article: Khawar Abbas, Hazur Muhammad Sabir, Anam Shehzadi, and Qamar Abbas, "IImpact of Workers' Remittances on Household Welfare in District Jhang (A Case Study of Tehsil 18 Hazari).” Journal of Finance and Economics, vol. 2, no. 4 (2014): 131-135. doi: 10.12691/jfe-2-4-5.

\section{Introduction}

This is the age of globalization. Many countries adopted open policies to connect their people with the world community. This is the main cause of the movement of factors of production from one country to another country. The movement of the people from one country to another country or within the geographical boundary of a country is called migration. The volume of migrated people has been increased $14 \%$ during the period of 1990 to 2000 in the world. About 175 million people were living outside from their home countries in2002 and it has been expected that this figure reached at 250 million in 2050 [20]. Shaw and Ratha [22] said that from 191 million migrant people, 78 million belong to developing countries who were the $80 \%$ of total migrated people in the world.

Pakistan is the $5^{\text {th }}$ largest country of the world in term of migration of the people [26]. The main reason for the migration from Pakistan are the pull factors such as massive unemployment, high poverty rate, wage gap between Pakistan and other countries, terrorism, law and order situation etc. Many people migrated for better education, better health facilities and many other factors which attract the people to migrate from Pakistan.

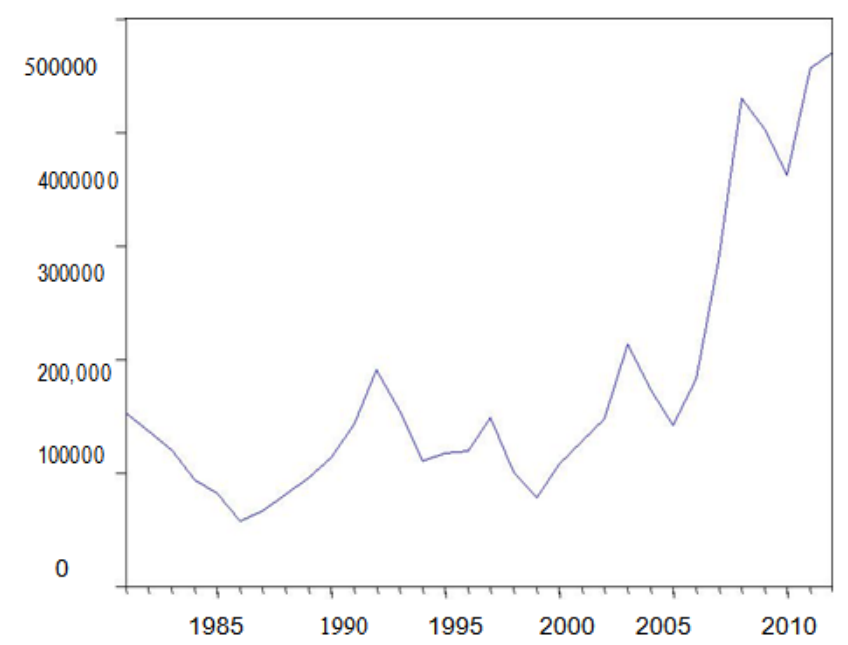

Figure 1. Trend of Migration from Pakistan during 1982 to 2011 (Source: Bureau of emigration and overseas employment [4]) 
The above figure shows the fluctuations in the trend of migrated people during 1982 to 2010. The main reason for the declined in migration in 2000 was to be the banned from other countries for the people of Pakistan. In 1999, many countries such as U.A.E, Bahrain, Qatar and Kuwait banned the employment visas for Pakistanis. After the period of 2001, the trend of migration is increasing persistently.

When the migrated people send their earning to support their families in the form of cash and goods is called worker's remittances [23]. The inflow of remittances is continuously increasing in Pakistan and contributing a significant role for the balance of payment improvement and made wonderful contribution in the foreign exchange earnings of Pakistan. The workers' remittances reach on its peak in the history of Pakistan during the last fiscal year 2011 and 2012. It has been estimated that about 13186.58 \$ million remittances received in the last fiscal year which was $17.73 \%$ growth in the inflow of remittances as compare to the fiscal year of 2010 and 2011 [22].

There are confusion among the people about the impact of remittances on household welfare, such as food, health, education and cloth etc. Some People think that remittances receives households do not participate in workforce and reduce the impact of remittances. There is no guarantee that recipient households spent their income on expenditure such as health, education food etc because in some time they save it for future purposes. Whereas other group of people says that majority of the recipient households spend their income to meet their basic needs such as food, education, health and cloth [23].

Workers' remittances play a very important role for the improvement of the life of receiving households. The emigrant people send their earnings to their families in the origin countries which decrease the budget constraint and help the people as a safety net in the time of economic crises [11]. In 2005, McKenzie and Hildebrandt said that remittances improve the health status of children by providing better nutrition. They increased the birth weight and reduced infant mortality rate. In 2006, LopezCordova estimates that $1 \%$ increase in the remittances share decreased the infant mortality rate by $1.2 \%$. Although remittances and migration are very beneficial for recipient households but people also pay some social and economic costs. Remittances increase the dependency behavior among the households because remittances receiving households do not interest in doing work [15]. It generates idleness among recipient households [5]. Migration of the people also creates some social problems such as fatherless children and broken families etc. The absence of the man in the house creates psychological pressure on the women to take the strong decisions without their men [17].

The main focus of this investigative research was to assess the impact of workers' remittances on household welfare in Tehsil 18 Hazari because it was newly established Tehsil of District Jhang and mostly Odd and Kashmiri families dominated in this Tehsil and their people lived in foreign countries in majority. Poverty of the people is a major problem for Pakistan. It has been estimated that about $40 \%$ of its population was living below the poverty line in 2010. District Jhang is the backward area of province Punjab where a number of people are living below the poverty line. So it has been desired that examined some determinants which influence the level of poverty in this region.

\subsection{Objectives}

- To estimate the impact of remittances on household welfare in Tehsil 18 Hazari.

- To check the impact of remittances on poverty of household in Tehsil 18 Hazari.

- Suggestions and policy recommendation

\section{Review of Literature}

Ureta and Edwards [6] conducted the study for investigating the impact of remittances on human capital such as health and education in the economy of El Salvador. The results of the study indicated that remittances positively affect the education and health status of the migrant households. Quartey [19] investigated the impact of migrant remittances on household welfare in Ghana. The results of the randomeffects GLS regression model showed that remittances had a positive and significant impact on household welfare and beneficial for minimizing shocks. Raihan et, al. [20] examined the impact of remittances on household welfare in Bangladesh. The results were in the favor of the hypothesis that remittances increased economic growth and reduced poverty in Bangladesh. Latif and Ashfaq [13] examined the impact of remittances on rural economy and found that monthly expenditures of remittances receiving households increased by $41 \%$ while expenditures on food increased by $31 \%$.

\section{Material and Methods}

\subsection{Data}

The data was collected from the study area through simple random sampling technique. The size of the sample was around 280 households from which 140 were remittances receiving households and 140 were remittances non-receiving households. For this purpose, 10 villages were selected which covered all the union councils of tehsil 18 Hazari.

\subsection{Methodology}

\subsubsection{Impact of Remittances on Household Welfare}

Workers' remittances play a very important role for the improvement of the life of receiving households. The emigrant people send their earnings to their families in the origin countries which decrease the budget constraint and help the people as a safety net in the time of economic crises. Some people save that money and invest it in future which create job opportunities and decrease unemployment while other spends this on durable and non durable goods [11]. Many studies show that remittances improve the welfare of the households either they spend on basic necessities or save this and invested it in future [16].

Household expenditures were used as a proxy variable to check the welfare of the household [19]. Expenditures 
were divided into per capita total expenditures, per capita expenditures on education, per capita expenditures on food and per capita expenditures on education. The welfare function for the household groups was estimated by the ordinary least square (OLS) following Okojie [19] and Ufomada [24].

\section{Model 1}

$\operatorname{Exp}=\mathrm{f}\left(\beta_{0}+\beta_{1} \mathrm{HH}\right.$ age $+\beta_{2} \mathrm{Edu}+\beta_{3}$ Rem $+\beta_{4} \mathrm{GH}+$ $\left.\beta_{5} \mathrm{DR}+\beta_{6} \mathrm{MS}+\beta_{7} \mathrm{ES}+\beta_{8} \mathrm{HS}+\beta_{9} \mathrm{Liv}\right)$.

\section{Variable description}

Exp = Per capita expenditures of household

$\mathrm{HH}$ Age $=$ Age of the household head (In years)

Edu = Education of household head(Years of schooling)

Rem $=$ Remittances $(1$ for remittances receiving and 0 for non-receiving)

$\mathrm{GH}=$ Gender of household head ( 1 for male and 0 for female)

$\mathrm{DR}=$ Dependency ratio

MS = Marital status ( 1 for married and 0 for unmarried)

$\mathrm{ES}=$ Employment sector (1 for non-agriculture and 0 for agriculture)

HS = House size( Number of persons per room),

Liv $=$ Total number of animals(Large+ small animals $)$.

Because per capita expenditures of the household was in continuous form so Ordinary Least Square (OLS) method was used to check the impact of different socio economic variables on household welfare.

\subsubsection{Impact of Remittances on Poverty of Household}

There are two main channels through which remittances affect the poverty of household. The flow of remittances towards the neediest people and directly affect household

standard. On the other hand it reduces the budget constraints and provide income to people start business and generate more income [1].

\section{Model 2}

Pov $=\mathrm{f}\left(\beta_{0}+\beta_{1} \mathrm{HH}\right.$ age $+\beta_{2} \mathrm{Edu}+\beta_{3}$ Rem $+\beta_{4} \mathrm{GH}+$ $\left.\beta_{5} \mathrm{DR}+\beta_{6} \mathrm{MS}+\beta_{7} \mathrm{ES}+\beta_{8} \mathrm{HS}+\beta_{9} \mathrm{Liv}\right)$.

\section{Variable description}

Pov $=$ Household poverty ( 1 for poor and 0 for non poor) $\mathrm{HH}$ Age = Age of the household head (In years)

Edu = Education of household head(Years of schooling)

$\mathrm{GH}=$ Gender of household head ( 1 for male and 0 for female)

$\mathrm{DR}=$ Dependency ratio

MS = Marital status ( 1 for married and 0 for unmarried)

$\mathrm{ES}=$ Employment sector (1 for non-agriculture and 0 for agriculture)

HS = House size( Number of persons per room)

Liv $=$ Total number of animals(Large + small animals $)$

Rem $=$ Remittances $(1$ for remittances receiving and 0 for non-receiving).

The poverty of the households was measured through Poverty line. The people whose monthly per capita net income was less than 3750 rupees were below the poverty line and assigned poor and if above the Poverty line then it was non poor. Because the dependent variable which is poverty has two categories ( poor $=1$, Non poor $=0$ ), so binary Logit was used here to check the impact of Remittances on the Poverty of Households [10].

\section{Results and Discussion}

Table 1. Results of binary logit regression analysis

\begin{tabular}{|c|c|c|c|}
\hline Variables & Coefficients & Sig & Odd Ratio \\
\hline $\mathrm{GH}$ & -.74 & .35 & .47 \\
\hline MS & .48 & .48 & 1.62 \\
\hline ES & .30 & .34 & 1.35 \\
\hline HS & .37 & .012 & 1.45 \\
\hline DR & .041 & .06 & 1.04 \\
\hline Liv & -.051 & .013 & .95 \\
\hline Rem & -2.24 & .000 & .106 \\
\hline Age of $\mathrm{HH}$ & .002 & .89 & 1.002 \\
\hline Edu of $\mathrm{HH}$ & -.07 & .04 & .92 \\
\hline
\end{tabular}

Dependent variable $=$ Poverty (1 for poor and 0 for non-poor).

The results of Table 1 shows that education of household head, total number of animals and remittances are beneficial for decreasing the probability of being poor while house size and dependency ratio increase the probability of being poor. The odd ratio of education is .92 which shows that if the education of household increase by 1 year then .08 time less chances of the household to becoming poor because the educated people have more opportunities to get job. It also increase the efficiency and productivity of people which increase their income [9]. The coefficient of livestock shows that If the volume of animals increased by 1 unit then there are .05 time less chances to becoming poor. The reason behind this was that mostly, the people of selected population were living in rural areas and majority of them depended on the stock of animals, so this was to be the main cause to increase their income. The odd ratio of foreign remittances is .10 which shows that those people who are receiving remittances have .90 times less chances to become poor as compared to those who were not receiving remittances. Raihan et al [20] also found a significant impact of remittances for reducing the level of poverty in Bangladesh. The negative sign of House size indicates that when the number of people increased then their chances to become poor increase because an additional member of household mean an additional mouth to food and an additional body to cloth, house and carter etc [9]. More over larger the house size, the more difficult for the household to meet the basic requirements such as education for children, proper nutrition and adequate housing etc [25].

On the other hand, Gender of household head, Age of household head, Marital status of household, Employment status of household have not significant role for changing the poverty of households in selected sample [9]. 
Table 2. Regression on the key component of expenditures

\begin{tabular}{|c|c|c|c|c|c|c|c|c|}
\hline \multirow{2}{*}{ Variables } & \multicolumn{2}{|c|}{ Per capita total } & \multicolumn{2}{c|}{ Per capita food } & \multicolumn{2}{c|}{ Per capita edu } & \multicolumn{2}{c|}{ Per capita health } \\
\cline { 2 - 10 } & \multicolumn{2}{|c|}{ Expenditures } & \multicolumn{2}{c|}{ Expenditures } & \multicolumn{2}{c|}{ Expenditures } & \multicolumn{2}{c|}{ Expenditures } \\
\cline { 2 - 10 } & Coeff & T- value & Coeff & T- value & Coeff & T- value & Coeff & T- value \\
\hline GH & -.10 & -1.03 & -.046 & -.29 & -.07 & -.32 & -.129 & -.72 \\
\hline MS & -.19 & -2.25 & -.138 & -.96 & -.31 & -1.47 & -.38 & -2.42 \\
\hline HS & -.041 & -2.39 & -.073 & -2.68 & -.091 & -2.12 & -.068 & -2.14 \\
\hline Liv & .004 & 2.10 & .003 & .88 & .001 & .20 & .002 & .43 \\
\hline ES & .030 & .78 & .023 & .37 & .07 & .69 & .017 & .24 \\
\hline DR & -.044 & -1.92 & -.073 & -2.02 & -.13 & -2.41 & .033 & .79 \\
\hline Rem & .34 & 7.31 & .38 & 5.25 & .64 & 5.19 & .58 & 6.79 \\
\hline Age of HH & .002 & 1.44 & .003 & 1.12 & -.004 & -.85 & -.004 & -1.17 \\
\hline Edu of HH & .012 & 2.42 & .013 & 1.75 & .027 & 2.10 & -.015 & -1.72 \\
\hline Income & .12 & 4.51 & .16 & 3.6 & .227 & .003 & .11 & 2.19 \\
\hline
\end{tabular}

Dependent variables = Per capita total expenditures, Per capita food expenditures, Per capita education expenditures, Per capita health expenditures.

The above table shows that there is a negative and insignificant relationship between gender of household head and household welfare [25]. The coefficient of marital status shows that the per capita expenditures of married households are less than as compare to unmarried household [20]. The coefficient of house size has negative sign which indicate that when the number of people in a room increase then there per capita expenditures decreased. The reason for this is that increase in the volume of people in a room indicate there lower living standard. The results of education of household shows that when the education of household head increase then there expenditures also increased because educated people use better food, cloth etc. Lancaster et al [12] also found positive relationship between education of household head and whole families education expenditures. The coefficient of dependency ratio indicates that when the volume of dependent people increased then their per capita expenditures decreased [20]. The results implies that household welfare increases as the age composition of the household increases. This is consistent with life cycle hypotheses, which postulates that demographic variables effect consumption and welfare of the household. The positive sign of the household income shows that when the income of household increase then their expenditures also increase following the results of Keynesian consumption function and Milton Friedman permanent income hypothesis [7]. The results of Employment sector agrees with Ogbonna [18] who reported that the sector of economic activity affects ones consumption and those household whose occupations fall with in manufacturing, industry and services are better off than agriculture sector. The coefficient of remittances indicate that remittances receiving household spend more on food, cloth and education as compare to non receiving households [20].

\section{Conclusion}

The results of Ordinary least square (OLS) method shows that education of household head, total number of animals, monthly income and remittances had positive and significant impact while marital status of household, dependency ratio and house size had negative and significant impact on per capita total expenditures. On the other hand the results of binary logit model show that size of the house was a cause to increasing the level of poverty while education of household head, number of total animals and remittances was beneficial for reducing the poverty in Tehsil 18 Hazari.

\subsection{Suggestions and Policy Implications}

The govt might adopt those policies which increase the trend of remittances in the country such as by starting negotiations among the foreign countries which ban the visa's for Pakistani workers, to enlarge the skill of migrant workers for making them capable to compete with the people of other countries in the foreign countries, facilitate the migrant people with providing them credit for reducing budget constraints on feasible conditions and set up those institutions which are reliable and low cost

\section{References}

[1] Acosta, Calderon, c., Fajnzylber,p. and Lopez, H (2007). Remittances and development in Latin America. World economy, 957-987.

[2] Akanjie, B (1999). Differentials and patterens of gender responsibility in Tradeable crop agriculture in Nigeria. Paper presented at a conference on women farmers enhancing rights and productivity by center for development research, Bonn, Germany.

[3] Black, R. (2003). Soaring remittances raise new issues. Migration information source.

[4] Bureau of emigration and overseas employment, (2012).

[5] Chami., Ralph., Fullenkanp, C. and Jahan, S. (2005) Are immigrant remittances flows a source of capital for development? IMF working paper WP /03/189.

[6] Edwards, c., and Ureta, M. (2003). International migration, remittances and schooling: evidence from El- Salvador. Journal of development economics, 72(2), 429-461.

[7] Etim, N., Okons, S., and Akpabio (2011). Determinants of deprivation among part time Cassava farming households in the Humid tropic. International journal of Agricultural management and development, 1(1), 45-51.

[8] Hildebrandt, N and Mckenzie D. (2005), The effects of migration on child health in Mexico. In economia.2005.

[9] Iheke, O., and Nwaru, J. (2008). Comparative analysis of the mean output of rice and profit by men and women in rice production systems in Abia state of Nigeria. Agricultural journal, 3(2), 147151.

[10] Iheke, O. (2010). Impact of migrant remittances on efficiency and welfare of rural smallholder arable crop households in south eastern Nigeria. Ph.d Disertation Michael Okpara university of Agriculture, Umudike, Nigeria. 
[11] Khan, M. (2010). Socio- economic impact of overseas workers' remittances on the recipient households in district Sawabi, Pakistan. A Thesis for the fulfillment of the degree of doctor of philosophy in economics.

[12] Lancaster, G., Maitra, p (2006) Endogenous intra household balance of power and its impact on expenditures patterns: evidence from India. Economica 73(291), 435-460.

[13] Latif, M. and Ashfaq, M (2013). an Economic Impact of Remittances in Rural Economy. Pakistan journal of Agricultural sciences, 50(1), 147-153.

[14] Lopez, E and Cordova (2006) Globilization, migration and development: The role of Mexican migrant remittances. INTLITD Working paper. 20.

[15] Meins, R. (2007). Remittances: An introduction foundation for international migration and development.

[16] Nwaru,j., Iheke,o., and Onyenweaku,c.(2011). Impact of migrant remittances on the welfare of Arable crop farm households in Southeastern Nigeria. Human ecology review, vol(18), 159-166.

[17] Nyiri, P., and Saveliev, A. (2002). Glablizing Chinese migration: Trends in Europe and Asia. Aldershot, England and Burlington,Vt: Palgrave.

[18] Ogbonna, M.C (2011). Poverty levels and food demands in rural yam Farm households in south eastern Nigeria. Ph.d Disertation Michael Okpara university of Agriculture, Umudike, Nigeria.
[19] Okojie, C (2002). Gender and education as determinants of household poverty in Nigeria. Wider discussion paper No. 2002/37.

[20] Quartey. P. (2006). The Impact of Migrant Remittances on Household Welfare in Ghana. Final report submitted to African Economic Research consortium, Nairobi, Keynia.

[21] Raihan, M., Khondker, B., Sugiyarto, G. and Jha, S. (2009). Remittances and Household Welfare: A case study of Bangladesh. Working Paper series No. 189.

[22] Ramirez, C., Dominguez, M. and Morais, J. (2005). Cross Border: remittances, Gender and development, New yark. UN- INSTRAW.

[23] Ratha, D and Shaw W (2007) South- South migration and remittances. World bank working paper no.102.

[24] State bank of Pakistam, (2012). Report on workers' remittances in Pakistan.

[25] Ufomadu, A. (2011). Effects of commercialization on the welfare of arable crop Farm households in Abia state, Nigeria. Msc Theses, department of Agricultural economics, Michael okpara university of Agriculture, Umudike Nigeria.

[26] Ukoha, O., Maheja, R., and Nte, I. (2007). Determinants of Farmers welfare in Ebonyi state, Nigeria. Pakistan journal of Social sciences, 4(3), 351-354.

[27] World Bank. (2009). Migrant labor remittances in the south Asian region. Report No 42342. 